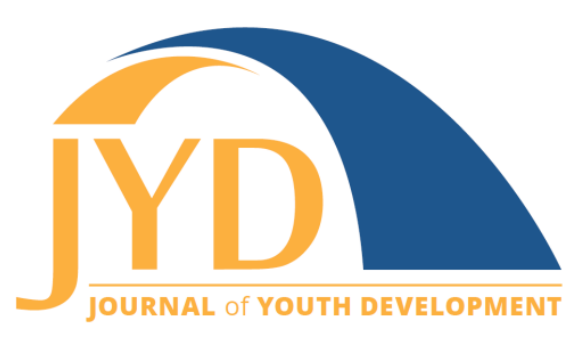

http://jyd. pitt. edu/ | Vol. 14 Issue 1 DOI 10.5195/jyd.2019.651 | ISSN 2325-4017 (online)

\title{
Theming, Co-Creation, and Quality of Structured Experiences at Camp
}

\section{Gary D. Ellis}

Texas A\&M University and Texas A\&M Agrilife Research

gellis1@tamu.edu

Jingxian Jiang

Texas A\&M University

kellyjiang@email.tamu.edu

\section{Andrew Lacanienta}

California Polytechnic University, San Luis Obispo

alacanie@calpoly.edu

\section{John Mark Carroll}

Texas A\&M AgriLife Extension Service

jmcarroll@ag.tamu.edu

\begin{abstract}
Lacanienta and his colleagues (2018) recently reported results of a study of the effect of themes on quality of experience of youths during summer camp activities. Existing literature suggested that theming activity sessions would have a strong main effect. Results, though, revealed an activity-by-theme interaction effect, i.e., themes seem to be effective in some activities but not others. In this follow-up study, we describe results of a secondary analysis revealing significant new insights regarding theme. Adding an indicator of campers' co-created, lived-experience theme into the models tested substantially clarified how objective theme, lived-experience theme, and activity interact in influencing the quality of structured experiences. This study, then, underscores the importance of including measures of participants'co-created lived experience as we seek to understand techniques that can be used to enhance the quality of youths' structured camp experiences.
\end{abstract}

Key words: co-creation, experience quality, deep-structured experience, theme, theory of structured experience

(cc) EY New articles in this journal are licensed under a Creative Commons Attribution 4.0 License. This journal is published by the University Library System, University of Pittsburgh and is cosponsored by the University of Pittsburgh Press. The Journal of Youth Development is the official peer-reviewed publication of the National Association of Extension 4-H Agents and the National AfterSchool Association. 


\section{Co-Created, Lived-Experience Theme}

A summer 2017 field experiment tested the effect of theming on quality of camper experiences. Lacanienta and his colleagues (Lacanienta, Ellis, Taggart, Wilder, \& Carroll, 2018) systematically applied and withheld themes for each of eight "core" camp activities during three sessions of a summer 4-H camp. Theme was operationalized as an objective phenomenon: a set of props and cues suggesting a story; a different place, time, and/or set of circumstances. During the themed challenge course activity, for example, props and cues invited campers to "become" part of a story about gold miners. Miners (the campers) had successfully extracted a large pot of gold from a remote mine in a distant wilderness. Bandits, though, were in "hot pursuit" of the miners, intent on stealing the gold. The miners had to climb a steep bluff (a cargo net) and quickly descend the opposite side via a rope slide (zip-line) to escape. A significant activity-bytheme interaction effect was found. That is, having a theme depended on the type of activity that was being themed. Theme had a stronger effect for some activities than others (e.g., challenge course had a stronger effect than fishing). Further, the presence of a theme decreased experience quality in two of the eight activities (rifle shooting and fishing). This interaction effect was unanticipated; the experience industry literature (e.g., Pine \& Gilmore, 2011) implies that theme has a main effect on experience quality (i.e., theme should directly increase experience quality), regardless of the activity context. Results thus indicated a need for further inquiry into methodological and conceptual issues associated with research on the effects of theme on structured experiences within the context of camp.

The objective approach to operationalizing theme used by Lacanienta and his colleagues (2018) provided insight into effects of props and cues providers may introduce to the activity context, but it did not capture campers' subjective, lived experiences in a themed story. Campers may choose to co-create (e.g., Prahalad \& Ramaswamy, 2004) a lived experience in any way they choose. Campers may spontaneously interact with other participants to create themed stories, or they may independently create their own imaginary stories. Thus, a camper standing in shooting position at the archery range might spontaneously imagine that she or he is shooting arrows at a terrible beast intent on destroying the earth. Rich opportunities for co-creation are at hand during a camp session due to the immediate presence of other campers of similar ages, who have shared interests and experiences. The purpose of this study was to evaluate the effect of the independent and joint effects of objective theme, lived-experience theme, and activity on each of three measures of experience quality. Specifically, through secondary analysis of the Lacanienta et al. data, we examined the effects of co-created, lived-experience theme (LET), objective theme, activity, and their interactions on three measures of quality of immediate experience: perceived value of time spent in the activity, delight, and prevalence of deep experience. 


\section{Co-Created, Lived-Experience Theme}

\section{Significance: Design Elements in Immediate Experience Research}

Notable interest exists among scholars and youth organization leaders in learning best practices for structuring immediate experiences that occur within youth programs (e.g., 4-H meetings, camp activity sessions, sport competitions or practices). As research on structured experiences proceeds, best practices in designing those experiences must also be followed. Beymer, Rosenberg, Schmidt, and Natzger (2018), for example, used experience-sampling methods to understand in-situ ("momentary") engagement of a sample of 10- to16-year-old youth during sessions of nine summer STEM programs. Findings indicated that choice and positive affect during structured experiences independently promote in situ engagement. More broadly, based on input from an elite panel of authorities, Eccles and Gootman (2002) proposed eight key features that should be reflected in any given session of a youth program: safety; structure; supportive relationships; shared sense of belonging; support for efficacy; opportunity for skillbuilding; and integration of family, school, and community. The HighScope Educational Research Foundation (Smith \& Hohmann, 2005) produced a similar list of features: youth voice, safe environment, supportive environment, interaction, and engagement.

The effect of theming on engagement and related in-situ subjective states is one of the areas of inquiry on structured experiences. Many camps use experience-structuring strategies (e.g., theme, personalization, memorabilia) shared with organizations in tourism and leisure industries (e.g., Pine \& Gilmore, 2011; Ellis, Lacanienta, \& Freeman, 2018). Theming is prominent among these strategies (Merhige, 2014). Extensive anecdotal evidence suggests that theme elevates experience quality, but research on theming is in its infancy (Lacanienta et al., 2018). From a behavioral science perspective, little is known about how to design and implement themes, or the effect of theming on the lived experience of participants. This research note adds to knowledge by evaluating the interacting effects of activity, objectively-defined theme, and cocreated lived-experience theme.

\section{Method}

\section{Data}

We conducted secondary analysis of the Lacanienta et al. (2018) data. Lacanienta et al. collected 1,847 experience observations (i.e., one experience observation from one participant in one activity) from 231, 8- to17-year-old youth in a residential 4-H camp. Over a 3-day period, campers rotated through eight core activity sessions: challenge course, archery, rifle shooting, 
Journal of Youth Development | http://jyd.pitt.edu/ | Vol. 14 Issue 1 DOI 10.5195/jyd.2019.651

\section{Co-Created, Lived-Experience Theme}

kayaking, fishing, crafts, swimming, and dance. The sessions included both girls and boys, but the majority (61.5\%) were girls.

\section{Measurement}

Campers received questionnaire booklets containing immediate experience quality and LET measures for each of the eight core activities. Immediate experience quality measures were a) perceived value of time spent, b) delight, and c) prevalence of deep experience during the activity (Ellis, Freeman, Jiang, \& Lacanienta, 2018). A brief description of each measure follows.

\section{Lived-Experience Theme}

LET was derived from an approach to measuring theme used by a leading international theme park provider (Disney Corporation). Campers rated, "I felt like I was inside a story" on a 10point slider scale. Anchor points ranged from "none of the time" to "all of the time." LET was included in the original data set (i.e., Lacanienta et al., 2018), but was not incorporated into the statistical models tested.

\section{Perceived Value of Time Spent}

Perceived value of time spent is defined as "the individual's degree of contentment with her or his decision to participate in the structured experience" (Ellis, Taggart, Martz, Lepley, \& Jamal, 2016). Five items were included on the questionnaire:

- This was an excellent use of my time.

- I am glad I chose to do this.

- I made a good choice when I decided to do this.

- I wish I had spent my time doing something else. (reverse-coded for scaling)

- $\quad$ This meeting was worth the time I put into it.

Reliability coefficients of .82 (Ellis et al., 2016) and .93 (Taggart, 2017) were previously reported. Evidence of validity is also present. The measure of perceived value of time spent has produced positive correlations with perceptions of safety and support in youth settings, as well as three indicators of the quality of structured youth experiences: engagement, meaningfulness, and satisfaction (Ellis et al., 2016). The alpha reliability estimate for the current study was .94. 


\section{Delight}

Delight is an extreme form of satisfaction (Oliver, 2010; Schneider \& Bowen, 1999; Torres \& Kline, 2006, 2013). A single-item graphic depicting a smiley face asked participants, "Please circle the face that best shows how much you liked or disliked this activity?" Five reference points included delighted ( core $=5$ ), satisfied (score $=4$ ), so-so (score $=3$ ), dissatisfied (score $=2)$, and disgusted (score $=0$ ).

\section{Prevalence of Deep-Structured Experience}

Deep structured experience (DSE) is "a state of effortless concentration during which individuals lose (a) their sense of time, (b) their thoughts about themselves, and (c) awareness of their problems. Participants have a genuine interest in the activity in which they are involved and a strong desire to continue doing that activity" (Ellis, Freeman, Jamal, \& Jiang, 2019, p. 9). DSE was measured using six sliding scales:

- During this activity, time flew by (time passed more quickly than usual).

- During this activity, I was "in the zone."

- During this activity, I was totally focused on this activity.

- During this activity, I thought only about the activity (my attention did not wander).

- During this activity, things seemed to be happening automatically for me.

- During this activity, I was good at this activity.

Participants placed an X along a $130 \mathrm{~mm}$ line anchored by "none of the time" and "all of the time." Scores were calculated by dividing the distance (in millimeters) from the beginning of the line to the $\mathrm{X}$ by 1.3 , allowing for a range of scores between 0 and 100 .

\section{Design and Analysis}

Lacanienta et al. (2018) used a two-factor (camp session-by-activity) repeated measures design. Each camper participated in multiple activity sessions. No activity sessions during one camp session were themed, all activities during another session were partially themed, and the third session activities were all fully themed. Theme was operationalized by using props, cues, and an imaginary storyline for each of the eight core activities. Measures of LET and experience quality were taken immediately after each activity session. Linear mixed modeling was used to test hypotheses in our secondary analysis of data. Results and conclusions from these analyses were contrasted with results reported by Lacanienta et al. (2017). 


\section{Co-Created, Lived-Experience Theme}

\section{Results}

Results show a strong and statistically significant effect of the three-factor interaction of objective theme, LET, and activity. Objective theme, LET, and activity all operate in conjunction to affect the quality of campers' immediate experiences. Test statistics ( $F$ ratios) and effect size/association strength statistics ( $R^{2}$ PRE) are reported in the Appendix. Effect sizes for this three-factor interaction were substantial: $R^{2}$ PRE values were $.39, .45$, and .56 for the linear models of deep experience, perceived value, and delight, respectively. Interpretation of this three-factor interaction is challenging, given that the design included eight activity types, three theme conditions (full, partial, and none) and the continuous measure of LET. Thus, to facilitate interpretation, we calculated means per activity, for the extreme, polar opposite conditions: where objective theme (full or partial) was present and LET was high (at or above the $66^{\text {th }}$ percentile) vs. objective theme absent and LET low (at or below the $33^{\text {rd }}$ percentile). As Table 1 reveals, substantial differences existed between the means of these extreme groups, and substantial variation in effect size across the core activities is evident. The smallest mean difference was $15.6 \%$ (archery, perceived value) and the largest was $115.7 \%$ (challenge course, deep experience). The average increase of deep structured experience, perceived value of time spent, and delight across high vs. low themed conditions for all activities was $45.9 \%$ $(S D=22.3 \%)$. 
Co-Created, Lived-Experience Theme

Table 1. Means per Activity for Theme Present and High LET vs. Theme Absent and Low LET

\begin{tabular}{|c|c|c|c|c|c|c|c|c|c|}
\hline \multirow[b]{2}{*}{ Core activity } & \multicolumn{3}{|c|}{ Deep experience means } & \multicolumn{3}{|c|}{ Perceived value means } & \multicolumn{3}{|c|}{ Delight means } \\
\hline & $\begin{array}{l}\text { Themes: } \\
\text { Present } \\
\text { and LET } \\
\text { high }\end{array}$ & $\begin{array}{l}\text { Themes: } \\
\text { Not } \\
\text { present } \\
\text { and LET } \\
\text { low }\end{array}$ & $\begin{array}{l}\% \\
\text { Difference }\end{array}$ & $\begin{array}{l}\text { Themes: } \\
\text { Present } \\
\text { and LET } \\
\text { high }\end{array}$ & $\begin{array}{l}\text { Themes: } \\
\text { Not } \\
\text { present } \\
\text { and LET } \\
\text { low }\end{array}$ & $\begin{array}{l}\% \\
\text { Difference }\end{array}$ & $\begin{array}{l}\text { Themes: } \\
\text { Present } \\
\text { and LET } \\
\text { high }\end{array}$ & $\begin{array}{l}\text { Themes: } \\
\text { Not } \\
\text { present } \\
\text { and LET } \\
\text { low }\end{array}$ & $\begin{array}{l}\% \\
\text { Difference }\end{array}$ \\
\hline Crafts & 78.87 & 43.22 & $82.5 \%$ & 4.67 & 3.59 & $30.1 \%$ & 4.96 & 3.56 & $39.3 \%$ \\
\hline Swimming & 81.08 & 49.29 & $64.5 \%$ & 4.72 & 3.77 & $25.2 \%$ & 4.90 & 3.79 & $29.3 \%$ \\
\hline Rifle shooting & 79.34 & 45.43 & $74.6 \%$ & 4.72 & 3.67 & $28.6 \%$ & 4.95 & 3.53 & $40.2 \%$ \\
\hline Challenge course & 78.26 & 36.28 & $115.7 \%$ & 4.88 & 3.22 & $51.6 \%$ & 4.93 & 3.00 & $64.3 \%$ \\
\hline Kayaking & 80.69 & 47.45 & $70.1 \%$ & 4.73 & 3.55 & $33.2 \%$ & 4.87 & 3.27 & $48.9 \%$ \\
\hline Fishing & 77.84 & 53.00 & $46.9 \%$ & 4.74 & 3.97 & $19.4 \%$ & 4.86 & 3.85 & $26.2 \%$ \\
\hline Archery & 81.77 & 53.52 & $52.8 \%$ & 4.83 & 4.18 & $15.6 \%$ & 4.95 & 3.92 & $26.3 \%$ \\
\hline Dance & 80.42 & 50.15 & $60.4 \%$ & 4.75 & 3.92 & $21.2 \%$ & 4.90 & 3.64 & $34.6 \%$ \\
\hline
\end{tabular}

Note. Groups represented by the columns are a) objective theme (full or partial) present and LET $>66^{\text {th }}$ percentile vs. b) objective theme not present and LET $<33^{\text {rd }}$ percentile. Maximum possible scores are 100, 5, and 5 for deep experience, perceived value, and delight, respectively. 


\section{Co-Created, Lived-Experience Theme}

Central to the purpose of this paper is the contrast between results summarized in the previous paragraph and results of the original study. Recall that the original study examined the twofactor interaction effect: objective theme-by-activity. The current analysis, in contrast, tested a three-factor interaction: objective theme-by-LET-by-activity. As Table 2 reveals, addition of LET to the model yields substantially new insight into what impact objective theme may have on the quality of immediate experiences of campers. The respective interaction effects are significant in both models, but the percent of variance explained increases dramatically in the three-factor interaction model. For the deep experience measure, effect size ( $\left.R^{2}{ }_{\text {PRE }}\right)$ increased from .03 to .39. For perceived value, the two-factor interaction $R^{2}{ }_{\text {PRE }}$ is .05 , and in the three-factor interaction model, $R^{2}{ }_{\text {PRE }}$ is .46 . Results for delight are consistent: .04 for the two-factor interaction model and .57 for the three-factor interaction model. When objective theme is present and campers report feeling like they were in a story, experience quality increases dramatically for all types of activities. 
Co-Created, Lived-Experience Theme

Table 2. Contrast of Results and Conclusions for Two Models

\begin{tabular}{|c|c|c|}
\hline \multirow[b]{2}{*}{ Key contrast } & \multicolumn{2}{|c|}{ Theme operationalization } \\
\hline & $\begin{array}{l}\text { Objective theme and activity only in the design } \\
\text { (Lacanienta et al., 2018) }\end{array}$ & $\begin{array}{l}\text { Objective theme, activity, and LET in the design } \\
\text { (Current study) }\end{array}$ \\
\hline $\begin{array}{l}\text { Summary of hypothesis tests } \\
\text { about theme }\end{array}$ & $\begin{array}{l}\text { - Main effect of objective theme not significant } \\
\text { Two-way interaction effect (theme by activity) is } \\
\text { significant for deep experience, perceived value, } \\
\text { and delight, all } p<.001\end{array}$ & $\begin{array}{l}\text { - Main effect of objective theme not significant } \\
\text { - Three-way interaction effect (objective theme } \times \\
\text { LET } \times \text { activity) significant for deep experience, } \\
\text { perceived value, and delight, all } p<.001\end{array}$ \\
\hline $\begin{array}{l}\text { Summary of nature of } \\
\text { relations }\end{array}$ & $\begin{array}{l}\text { Effect of theme is weak overall, and stronger for } \\
\text { some activities than others } \\
\text { Theme may be contraindicative for some } \\
\text { activities (Fishing and Dance) }\end{array}$ & $\begin{array}{l}\text { - Effect of objective theme and LET is very strong } \\
\text { and positive for all activities } \\
\text { - Objective theme and LET operate together to } \\
\text { elevate experience quality for all activities }\end{array}$ \\
\hline $\begin{array}{l}\text { Summary of strength of } \\
\text { relations }\end{array}$ & $\begin{array}{l}\text { - Effect is weak } \\
\text { Plot of means of the three quality of experience } \\
\text { measures suggests that theme may be } \\
\text { contraindicative for some activities }\end{array}$ & $\begin{array}{l}\text { - Effect is very strong } \\
\text { - The interaction of objective theme and LET } \\
\text { substantially elevates experience quality in all } \\
\text { activities }\end{array}$ \\
\hline $\begin{array}{l}\text { Implications for structuring } \\
\text { experiences for campers }\end{array}$ & $\begin{array}{l}\text { Introducing storylines, props, and cues seems to } \\
\text { have a stronger effect in some activities more } \\
\text { than others. } \\
\text { - Theme may diminish experience quality in some } \\
\text { types of experiences }\end{array}$ & $\begin{array}{l}\text { - Objective themes substantially elevate quality of } \\
\text { experience in all activity types if participants have } \\
\text { LETs } \\
\text { - The effect of the interaction between objective } \\
\text { theme and LET is strong overall, but is much } \\
\text { stronger in some activities than others }\end{array}$ \\
\hline
\end{tabular}




\section{Co-Created, Lived-Experience Theme}

\section{Discussion}

The purpose of this study was to evaluate the independent and joint effects of objective theme, LET, and activity on each of three measures of experience quality. Results were contrasted with a previous analysis that did not include LET in the models. The three factors were found to interact. The strength of the interaction effect on all three indicators of experience quality was substantial. Activities, co-creation, and attention to a storyline are thus very important in determining the efficacy of an attempt to integrate a theme.

Limitations of the study must be noted. Negative skewness and positive kurtosis in the data are noteworthy. That is, participant responses were quite high (e.g., on a 5-point scale many responses were three or higher). These non-normal distributions indicate the need for improved measurement. A "ceiling effect" (i.e., a lack of variance) is evident; the response scales were not sufficient to generate potentially discriminating variance. Future data collection in youth camp settings might benefit from measures that afford greater opportunity for variability. Additionally, this study was a field experiment instead of a controlled laboratory experiment. Thus, fewer controls of potential confounding variables were in place. Also, it is important to note that the challenge of testing the effect of theme in a field experiment is complex. Theme is defined as a set of tangible and intangible cues that suggest a different time, place, set of circumstances, and a coherent storyline. These cues can thus be present in any activity, but the storyline will differ depending on the activity context. For example, in the current study a storyline about marauding bandits was in place at the challenge course. Whereas a storyline about the world's largest catfish was in place during the fishing activity. In a laboratory setting theme can be operationalized in a more controlled manner.

This study provides a number of implications for practice. Some points of consideration for youth program providers to consider are suggested by the questions below:

- How might you integrate a theme into your programs?

- What story does your current program tell?

- How might you increase the vividness of the storyline (exposition, rising action, climax, declining action, dénouement; Freytag, 1898) to youth participants?

- How might you facilitate "buy-in" that co-creates lived experience of theme?

- Can a consistent storyline be woven into many different types of activities? A camp session might, for example, follow a consistent theme from popular media such as Star Wars or Harry Potter. 
Co-Created, Lived-Experience Theme

Continuing research is needed. Perhaps the next questions to ask are: What actions can providers take to encourage participants to co-create the experience by "joining" the imaginary story? and What elements of an objective theme are most influential in securing camper engagement in making theme a lived experience? Greater understanding of theme may follow from the research on common elements of a storyline. Laurel (1993) proposed that dramatic stories are comprised of the following phases: (a) exposition, (b) inciting incident, (c) rising action, (d) crisis, (e) climax, (f) falling action, and (g) denouement. Campbell (2008), Freytag (1898), and Propp (1968) have proposed different variations of this morphology of a story. Future research on theme might focus on how providers might invite participation in an imaginary storyline at each phase of a themed experience.

\section{References}

Beymer, P. N., Rosenberg, J. M., Schmidt, J. A., \& Naftzger, N. J. (2018). Examining relationships among choice, affect, and engagement in summer STEM programs. Journal of Youth and Adolescence, 476), 1178-1191. doi:10.1007/s10964-018-0814-9

Campbell, J. (2008). The hero with a thousand faces. (3 ${ }^{\text {rd }}$ ed.). Princeton, NJ: Princeton University Press. Eccles, J. S. \& Gootman, J. A. (2002). Community programs to promote youth development. Committee on community-level programs for youth. Washington, DC: National Academy Press.

Ellis, G. D., Freeman, P. A., Jiang, J., \& Lacanienta, A. (2018). Measurement of deep structured experiences as a binary phenomenon. Annals of Leisure Research, 1-8. doi:10.1080/11745398.2018.1429285

Ellis, G., Freeman, P., Jamal, T., \& Jiang, J. (2019). A theory of structured experience. Annals of Leisure Research. 1-22. doi:10.1080/11745398.2017.1312468

Ellis, G., Lacanienta, A., \& Freeman, P. (2018). Reducing attrition from youth programs through structuring deep, valued, and impactful experiences for youth. In Witt, P. \& Caldwell, L. (Ed.), Youth development: Principles and practices in out-of-school time settings (pp. 351-387). Urbana, IL: Sagamore Venture.

Ellis, G. D., Taggart, A. S., Martz, J., Lepley, T., \& Jamal, T. (2016). Monitoring structured experiences during youth programs: Development of brief measures of perceived value and engagement. Journal of Youth Development, 11(3), 159-174. doi:10.5195/jyd.2016.469

Freytag, G. (1898). Technique of the drama (2 ${ }^{\text {nd }}$ ed.). Chicago: Scott Foresman.

Lacanienta, A., Ellis, G., Taggart, A., Wilder, J., Carroll, M. (2018). Does theming camp experiences lead to greater quality, satisfaction, and promotion? Journal of Youth Development, 13(1-2) doi:10.5195/jyd.2018.535

Laurel, B. (1993). Computers as theatre. Reading, MA: Addison-Wesley. 
Journal of Youth Development | http://jyd.pitt.edu/ | Vol. 14 Issue 1 DOI 10.5195/jyd.2019.651

\section{Co-Created, Lived-Experience Theme}

Merhige, J. (2014). Programming with a theme. Camping Magazine. Retrieved from https://www.acacamps.org/resource-library/camping-magazine/programming-theme

Oliver, R. L. 2010. Satisfaction: A behavioral perpsective on the consumer ( $2^{\text {nd }}$ ed.). Armonk, NY: M.E. Sharpe

Pine, B. J., \& Gilmore, J. H. (2011). The experience economy. Boston, MA: Harvard Business School.

Prahalad, C. K., \& Ramaswamy, R. (2004). Co-creation experiences: The next practice in value creation. Journal of Interactive Marketing, 18(3), 5-14. doi:10.1002/dir.20015

Propp, V. (1968). Morphology of the folk tale. Austin: University of Texas Press.

Schneider, B., \& Bowen, D. E. (1999). Understanding customer delight and outrage. MIT Sloan Management Review, 41(1), 35.

Smith, C. \& Hohmann, C. (2005). Full findings from the youth PQA validation study. Ypsilanti, MI: High/Scope Educational Research Foundation.

Taggart, A. (2017). Improving point-of-service quality of youth programs through structuring the immediate experience (Unpublished master's thesis). Texas A\&M University, College Station.

Torres, E. N., \& Kline, S. (2006). From satisfaction to delight: a model for the hotel industry. International Journal of Contemporary Hospitality Management, 18(4), 290-301. doi:10.1108/09596110610665302

Torres, E. N., \& Kline, S. (2013). From customer satisfaction to customer delight: Creating a new standard of service for the hotel industry. International Journal of Contemporary Hospitality Management, 25(5), 642-659. doi:10.1108/IJCHM-Dec-2011-0228 
Journal of Youth Development | http://jyd.pitt.edu/ | Vol. 14 Issue 1 DOI 10.5195/jyd.2019.651

Co-Created, Lived-Experience Theme

\section{Appendix}

Results of Tests of Statistical Hypotheses and Association Strength

\begin{tabular}{|c|c|c|c|c|c|c|c|}
\hline Criterion Variable & Factor(s) & $F$ & $d f_{1}$ & $d f_{2}$ & $\sigma_{r}^{2}$ & $\sigma_{\mu 0}^{2}$ & $R_{P R E}^{2}$ \\
\hline Deep experience & Objective themet $(\mathrm{T})$ & 2.96 & 2 & 218.38 & 374.47 & 175.85 & $<.01$ \\
\hline Perceived value & Objective theme $(T)$ & .77 & 2 & 208.55 & .78 & 0.26 & $<.01$ \\
\hline Delight & Objective theme $(T)$ & .22 & 2 & 206.91 & .78 & 0.19 & $<.01$ \\
\hline Deep experience & LET (L) & $1,159.64 *$ & 1 & $1,651.12$ & 193.34 & 112.97 & .39 \\
\hline Perceived value & LET (L) & $1,761.28^{*}$ & 1 & $1,592.17$ & .31 & .20 & .46 \\
\hline Delight & LET (L) & $2,264.27 *$ & 1 & $1,677.01$ & .35 & .08 & .49 \\
\hline Deep experience & Core activity (A) & $7.35^{*}$ & 7 & $1,460.10$ & 322.87 & 160.99 & .03 \\
\hline Perceived value & Core activity (A) & $12.00 *$ & 7 & $1,408.78$ & .65 & .23 & .06 \\
\hline Delight & Core activity (A) & $8.55^{*}$ & 7 & $1,463.90$ & .69 & .12 & .05 \\
\hline Deep experience & $\mathrm{T}$ by $\mathrm{L}$ & $350.01 *$ & 3 & 486.78 & 203.91 & 105.75 & .38 \\
\hline Perceived value & $\mathrm{T}$ by $\mathrm{L}$ & 483.34* & 3 & 474.34 & .34 & .18 & .44 \\
\hline Delight & $\mathrm{T}$ by $\mathrm{L}$ & $683.90 *$ & 3 & 401.24 & .30 & .07 & .56 \\
\hline Deep experience & $\mathrm{T}$ by $\mathrm{A}$ & $3.56^{*}$ & 23 & 886.40 & 356.92 & 175.95 & $<.01$ \\
\hline Perceived value & $\mathrm{T}$ by $\mathrm{A}$ & $4.15^{*}$ & 23 & 855.89 & .73 & .26 & $<.01$ \\
\hline Delight & $\mathrm{T}$ by $\mathrm{A}$ & $3.06 *$ & 23 & 933.27 & .75 & .18 & $<.01$ \\
\hline Deep experience & L by $A$ & $146.86 *$ & 8 & $1,486.06$ & 192.76 & 112.77 & .39 \\
\hline Perceived value & L by $A$ & $224.87^{*}$ & 8 & $1,432.18$ & .31 & .20 & .46 \\
\hline Delight & L by $A$ & $286.67^{*}$ & 8 & $1,493.44$ & .29 & .07 & .57 \\
\hline Deep experience & $T$ by $L$ by $A$ & $50.32 *$ & 24 & $1,188.42$ & 191.80 & 111.11 & .39 \\
\hline Perceived value & $T$ by $L$ by $A$ & 76.91* & 24 & $1,146.29$ & .31 & .20 & .46 \\
\hline Delight & $T$ by $L$ by $A$ & $96.54 *$ & 24 & $1,109.73$ & .29 & .07 & .57 \\
\hline
\end{tabular}

Note. * indicates $p<.001$. For all other $\mathrm{F}$ rations, $\mathrm{p}$ was greater than or equal to .05 . †Objective theme was operationalized by using props, cues, and a storyline. 